\title{
Implementation Model of Share Farming Agreements of Customary Land in Bali (A Study on Indigenous People's Legal Culture)
}

\author{
I Gusti Ngurah Dharma Laksana, I Gusti Agung Mas Rwa Jayantiari \\ Faculty member of Law and Society, Faculty of Law Udayana University
}

\begin{abstract}
This study aims to elaborate which in the long run can contribute to the policy model for the existence of the legal culture of the profit sharing agreement for the management of village-owned land in Bali. The realization is by tracing the procedures and contents of the share farming agreement on the management of customary or villageowned land in Bali, which in its use is based on the values of local wisdom and strengthens it into a legal culture. The method used is an empirical legal research method, namely legal research that analyzes and reviews existing data relating to the legal behavior of individuals or indigenous peoples in accordance with what is deemed appropriate by the rules and order of the legal value of the community concerned. The data source used is primary data, namely data obtained from direct sources in the research field, especially in the indigenous community of Bali and this research focuses on the profit sharing agreement for the management of village-owned land. Another approach to enriching information and analyzing data obtained is a comparison approach. Based on the research it can be stated that the implementation of the share farming agreement for village-owned land in general still exists in accordance with the rules of Balinese customary law through verbal meetings/agreements despite the dynamics of the procedures and contents of the agreement. This reflects that customary law as a living law is conceptualized as a legal system that is formed and originates from empirical experience that is deemed appropriate and has gained legitimacy from the customary authorities of local customs. Based on that fact, it can be concluded that the implementation of the agreement for the cultivation of customary land in Bali is built by compliance and legal awareness that is inherent and built by a positive and strong legal culture. As well as being cultivated in such a way that the aspects of legal culture appear to be well preserved in the indigenous community of Bali.
\end{abstract}

Keywords : Legal Culture, Share farming Agreement, Cultivation, Village Owned Land

DOI: $10.7176 / \mathrm{JLPG} / 85-04$

Publication date:May $31^{\text {st }} 2019$

\section{Introduction}

Essentially the Republic of Indonesia is an agricultural country whose livelihoods are largely dependent on land. Because humans and land have a very close relationship. There are two things that cause the land to have a very important position in customary law, namely because of the "nature" and "facts" of the land itself. When viewed from its nature, the land is the only asset, regardless of its circumstances, it remains as it is in its original state, not even infrequently because certain natural events of the land provide better benefits than the original condition. When viewed from the facts, land is a place to live and provide life and a place for the members of the community to be buried later after death (C. Dewi Wulandari, 2010:80).

In the literature of customary law, profit sharing transactions are known as "mengduai" (Minangkabau), "toyo" (Minahasa), "tesang" (South Sulawesi), "maro", "mertelu" (Central Java), "nengah", "jejuron" (Periangan) (Bushar Muhammad, 1988:117). According to Djaren Saragih, the share farming agreement is a legal relationship between a person who is entitled to land with another or the second party, where the second party is allowed to cultivate the land in accordance with the provisions, the yields of cultivating the land shall be shared by two people; the one who is entitled to the land and the person who cultivates the land (Djaren Saragih, 1984:97). Whereas according to Wulandari, the term of the above transaction occurs when the landowner gives permission to another person to work on the land with an agreement that those who get permission must give a portion (half if it is profit shared by two parties/memperduai or maro and one third if mertelu or jejoron) the land to the owner (C. Dewi Wulandari, 2010:93).

The function of land ownership rights as mentioned above is made productive without the owner working alone. The objects of the transaction are actually the labor and the plants, on the basis that the head of the partnership does not need to ratify the agreement, after all the certificate of agreement is rarely made. These transactions are generally entered into force at the time of planting and ends after the harvest (C. Dewi Wulandari, 2010:93).

Based on the description above, it is important internally the awareness in the adherence to the values of local wisdom, one of the few institutions that is still consistent, is a traditional village that is traditionally known by the Balinese people as the pakraman village or the dresta village that controls customary land. Only later for some reason, was there the surrender of druwe village land by Pakraman village to individuals (the pakraman villagers), 
the village residents, to make use of the customary land according to their needs. In addition, if viewed from the General Explanation number II point 7 Law No.5 of 1960 on the Basic Agrarian Policy Regulation allows the use of agricultural land by people who are not the owners, for example by implementing profit sharing by taking into consideration the aspects of justice and to prevent extortion methods. The provisions of customary law that apply in various regions are certainly diverse. In the meantime, the reference to the issue of the implementation of the share farming agreement according to customary law is very limited, in connection with the problem, it is necessary to conduct research on aspects of the legal culture of the implementation of share farming agreement of customary land with the following aims :

a. Reviewing the culture of law in the making of share farming agreements on the customary land in Bali.

b. Explaining the implementation of the contents of the share farming agreements on customary land in Bali.

\section{Materials and Methods}

The method used in this study is empirical legal research, namely legal research that examines and analyzes the legal culture of the procedure for making agreements for the utilization or cultivation of customary land. Research related to the legal culture of the agreement for the cultivation of customary land of druwe desa in the Balinese villages uses data and sources directly from the research field as primary data. Primary data is data that comes from the main source, namely the community (Salim. HS., H. and Erlis Septiana Nurbani, 2011:21), so that field research is needed in its implementation.

Processing and analysis techniques of data were obtained from the results of interviews with informants and respondents, which were then analyzed descriptively and qualitatively with the emphasis on the content analysis (Sumandi Suryabrata, 1992:85), also equipped with situational analysis, in the sense of analyzing specific situations that exist in certain events or circumstances. The results of the data analysis are presented in descriptive analysis by describing comprehensively the share farming agreements for the cultivation or utilization of village customary land, and then the discussion is carried out.

\section{Results}

The development of the study of law and culture in which the law is considered to be the embodiment of the system of cultural values of society, hence the recognition of a new term of legal culture as a compound between legal and cultural variables. The first term is considered to be born due to social forces that affect the workings of law in society, in the form of elements of the value of public attitudes related to legal institutions (Budi Agus Riswandi and Syamsudin., M, 2005:147).

When linked to the value structure that is formed in indigenous communities and become a legal culture that grows to build legal awareness of indigenous peoples, this is based on the customary legal system (Otje Saman Soemadiningrat, 2011:27). When viewed in reality, the values contained in the law are different from the values that have been embedded in the lives of indigenous peoples, this is clearly seen in the research carried out, even though the production sharing agreement has been regulated in Law No.2 of 1960 but in reality the agreement for profit sharing is not stated in written/oral form.

For more details, the procedures for the share farming agreement will be described based on Article 3 of Law No. 2 of 1960 which can be briefly explained in the following points :

a. Share farming agreements must be made in written form by landowners and share farmers/ tenant farmers before the chief of the village at the location of the land in question;

b. The making of share farming agreement must be witnessed by two witnesses, each from the owners and the share farmers;

c. The share farming agreement shall be validated by the head of the district;

d. The share farming agreement shall be announced by the chief of the village at each village meeting.

To overcome these obstacles and to intensify the implementation of the share farming agreement, the Agrarian Minister Regulation No. 4 of 1964 was issued concerning the Implementation Guidelines for Share Farming Agreements as amended by the Presidential Instruction of the Republic of Indonesia No. 13 of 1980 concerning Guidelines for Law No. 2 of 1960 concerning Share Farming Agreements. The procedure for making the above share farming agreement is not necessarily obeyed by the people. In reality, the implementation of the agreement in written form encountered difficulties and obstacles. Landowners and share or working farmers in the share farming agreement procedures are initiated with the people's meetings or called sangkepan held at the local village hall by approving agreements between landowners and prospective share or working farmers. The agreements made include :

a. Object of the share farming agreement;

b. The division of proceeds to be received by each of the parties (landowners and share or tenant farmers) including intercropping; 
c. Imposing other costs: seeds, fertilizers, pest control, planting costs, planting of protective crops, costs for weeding/shrubs and so on;

d. Period of share farming agreement;

e. The status of the share farming agreement if the cultivated land is transferred (sold, donated, etc);

f. The consequences of termination of the share farming agreement;

g. After reaching an agreement on the above matters (which are basically about the contents of the share farming agreement), then if mutually agreed upon, it can be made in the form of a written agreement.

The description above reflects that customary law as a living law is conceptualized as a legal system that is formed and originates from the empirical experience of the community in the past, which is considered fair or appropriate and has gained legitimacy from traditional authorities so that it is binding or must be obeyed (normative). The process of adherence to customary law, initially arises because of the assumption that every human being, from birth has been covered by norms that govern personal behavior for every legal act and legal relations that apply in a harmonious interaction. Thus, the community and its members carry out these normative commands without regard to them as coercion but because of the assumption that such orders are indeed supposed to be (duly).

This view is in line with the philosophy of Indonesian society, namely the participant's denominator, integralharmonious thoughts with the universe and expect the atmosphere to be in harmony, and balanced in social life (Otje Saman Soemadiningrat, 2011:27). Thus in reality the values of togetherness in the customary law community associated with legal culture will function as a "soul" that will revive all legal enforcement mechanisms established and applied in customary law communities. On the aspect of understanding the values and beliefs of indigenous peoples who are adhering to tradition values that have long been believed and maintained by local customary law communities.

According to the provisions of customary law, the amount of profit or proceeds sharing between the portion of landowners and the tenant or working farmers varies. This is due to several things, including: (1) the size of land available; (2) the number of working farmers who want to cultivate the land; (3) soil fertility conditions; (4) the strength of the position or status of the owners in the local community/area. In reality, since there is not much land available while the a lot of people want to become the tenant or working farmers, then often the working farmers are forced to accept the terms of the agreement which gives them an unfair sharing that is not in accordance with the labor and costs that have been used to cultivate the land concerned.

In order to obtain the best possible sharing, Article 7 paragraph (1) of Law No. 2 of 1960 stipulates the amount of the land portion which is the right of the share or working farmer and the landowner for each region of swatantra level II (now regency/city area) determined by the regent/mayor concerned with respect to the type of crop, the condition of the land, population density, donations collected before proportion sharing and economic factors as well as the local customary provisions.

In line with the provisions of Article 7 (1) of the Act 2 of 1960 mentioned above, the regent of Buleleng issued Decree No.132/592.3/4851/1982 of 31 December 1982 which stipulates the balance portion of the proceeds of land between the landowners and the share farmers as follows :

a. Wet Land

1) Rice crops : 2 to 1 (portion of landowner is 2 , and portion of share farmer is 1 );

2) Palawija crops $\quad: 1$ to 2 (the share portion for the landowner is 1 and the portion of the share farmer is 2 );

b. Dry land $\quad: 1: 2$ (the share portion for the landowner is 1 and the share farmer is 2 ).

It can be explained that the proportion of the share of the proceeds of land between the landowner and the share farmer shows that it is not in accordance with the sharing proportion stipulated in the legislation. The incompatibility can be described as follows :

a. For rice plants grown in rice fields using a ratio of 1:1 (landowner 1 and share farmer 1). The data shows that the portion of the proceeds sharing received by landowners and share farmer is not in accordance with the Decree of the Regent of Buleleng, but on the other hand the proportion is in accordance with Law No.2 of 1960.

b. For palawija crops: using a ratio of 1:1 (landowner 1 and share farmer 1). This shows that for palawija crops, the the proceeds sharing received by the landowner and share farmer is in accordance with the provisions of Article 7 paragraph (1) of Law No. 2 of 1960, on the other hand, the ratio of 1:1 (landowner 1 and share farmer 1) is not in accordance with the Presidential Instruction No.13 of 1980 and the Decree of the Regent of Buleleng No.132/592.3/4851/1982.

In the meantime, regarding the intercrops planted on share farming land, the following data was obtained : both the landowner and the share farmer state that the yield of the whole intercropping plant shall become the portion of the share farmer. However, under certain conditions or at certain times, in case the landowner requires it, the intended intercropping can also be enjoyed by the landowner, for example when there is a traditional/religious ceremony. 
Unlike the case with Law No.2 of 1960 which has provided strict guidance on the sharing proportion of the proceeds received by landowners and share farmers, so for perennial crops that are subject to the provisions of customary law, there are still varioussharing proportion. This is due to several factors, including : (1) the area or size of the land available; (2) the number of share farmers who want it; (3) condition of soil fertility; (4) the strength of the position or social status of landowner in the local indigenous community; (5) its relationship to the pledge given to the land owner; (6) plant age; (7) yields of intercrops, etc.

The research results obtained in the field show that in reality, the share farming agreement made between landowners and share farmers does not specify a certain period of time or the terms of agreement. The reasons can be described as follows :

a. The reason for the share farmer to make a share farming agreement without specifying a certain period of agreement : the share farmers are worried that if the time period specified clearly in the agreement has expired, the land may be taken back by the landowners.

b. The reason for the landowners to make a share farming agreement without specifiying a certain period og the agreement, namely : the landowners object to it because if the they need their land, they can be taken immediately at any time.

In practice, according to what has become a habit and carried out from generation to generation, the legal relations of the share farming agreement have been carried out in such a way on the basis of trust or good faith and procedures that are usually obeyed. The period of time that is not specified in the cultivation of land by the share or working farmers they feel worried that the land will be taken over during the planting period by the landowners; and this is very detrimental to the cultivator. The effect on the effectiveness of cultivating arable land will affect on the quality of the land cultivated. The working farmers will not cultivate the land optimally because of the uncertain duration of the planned time. As a result, the ways of cultivating the soil are not optimal so that the soil cannot produce well and this certainly has an impact on the quality of the soil and yields.

There is a condition that is not harmonious between landowners and the share farmers so that there is an assumption that they do not need to cultivate the land properly because the land can be taken away by the landowners at any time. Landowners are indeed as determined from time to time in the local village do not want to set a definite time period in the agreement. This will make it easier for the landowners to withdraw their land at any time.

The basic agreement is an agreement that becomes law for those involved in the agreement. In this case the rights and obligations arise in the share farming agreement between the landowners and the share farmers. Rights and obligations of landowners : a) The right to the portion of the proceeds in accordance with the agreement; b) The right to take back the share farming land if the landowners want it at any time; $c$ ) The right to terminate the share farming agreement if there is an appropriate reason; d) The obligation to provide the proceeds of the land to the share farmers in accordance with the proportion and agreement; e) The obligation to bear the costs for the cultivation of land that has been agreed upon. While the rights and obligations of the share or working farmers : a) The agreed share of the proceeds is the right of the share farmer; b) The right to terminate the agreement if there is an appropriate reason; c) It is obligatory for the share farmer to surrender the cultivated land if at any time the landowner wants it; d) It is obligatory for share farmer to surrender the land if there is a reason to terminate the agreement for the intended results; e) It is obligatory for the share farmers to bear the costs charged to them in accordance with the agreed agreement.

The share farming agreement not only regulates the rights and obligations agreed upon but also regulates the costs incurred, namely the costs borne jointly between the landowners and the share farmers, among others : the cost of seeds, fertilizer, pest control and planting costs, harvest costs, costs of planting protective crops, the cost of pruning, and the cost of cutting shrubs.

Alignment in the harmonization of law is an entry point. It is not only looking at the control of natural resources by the state but at the integration of human-centered regulation or more commonly called anthropocentric-it is not only for the authority owned by the government or the ruler as the state representative to make the rules. Legal certainty will be realized with rules that are made in accordance with formal procedures but if the integration of the aspects, even excluding the basic philosophy of legislation, does not become the basis of the harmonization, the purpose of the law will not be fully achieved. The negligence of the harmony between the rules will not create a good punitive situation for all partiesand will not achieve the objectives of the formulated law.

\section{Discussions}

The development of the study of law and culture in which the law is considered to be the embodiment of the system of cultural values of society, hence the recognition of a new term of legal culture as a compound between legal and cultural variables. The first term is considered to be born due to social forces that affect the workings of law in society, in the form of elements of the value of public attitudes related to legal institutions (Budi Agus Riswandi and Syamsudin., M, 2005:147). The concept of legal culture from Lawrence M. Friedman, in Derita Prapti Rahayu 
(Derita Prapti Rahayu, 2014:53) namely :

a. The legal culture refers to parts of culture in general (habits, opinions, ways to move social forces closer or away from the law.

b. A legal culture that determines when, why and how people treat law. Legal institutions or the legal process and why they use other institutions or do not use them at all. In other words, it is the cultural factor that transforms static legal structures and regulations into living laws.

c. Legal culture is the attitudes, values and opinions of society in dealing with law and the legal system, legal culture is the source of law.

d. Legal culture is a network of values and attitudes related to the law, which determines when, why and how the community obeys or rejects the law, determines what legal structure is used and what reasons and what legal rules are chosen to be applied and ruled out and the reason.

e. Legal culture is ideas, attitudes, hopes and opinions about the law maintained by citizens.

When it is linked to the implementation of the share farming agreement for the share farming of customary land according to the rules of Balinese customary law is how the allocation for indigenous peoples is maintained by prioritizing socioreligious values and harmonization of common life. Besides the existing authority, for example in formulating the rules through customary rules of awig-awig, the implementation of the law of community compliance is the main key in realizing the ideal goals of customary law. Values, customs and customary law as a cultural value system of a community of law society serves to organize and control the behavior of citizens and social life, in order to achieve the purpose of living together, namely public order and peace.

The cultural value system contains basic values related to the background of people's lives. Characteristics that are social religious in customary law inspire reliable legal culture of the community to enforce legal provisions with adherence to safeguard what indigenous peoples have as their communal wealth. This is a community legal culture and it is important that we see it in the current dynamics of the development of the Balinese customary land. In this aspect of legal culture, obedience to the share farming agreement of customary land is examined with the long-term intention of contributing to the overall national land policy in general.

Agreements for the share farming of customary lands by indigenous peoples if paruman/mutual agreement obeyed by the community members who control customary land means the operation of the network of values and attitudes related to the law, which determines when, why and how the community obeys or rejects the law, to ensure that the legal structure has been going well. Despite dealing with the dynamics that have a direct influence on the land, the network of values of compliance culture is used as a basis so that despite the fact that there is a real shift in the function of customary land use, it is maintained in accordance with the philosophy of common life believed by the Balinese customary law community.

\section{Conclusions}

The implementation of the share farming agreement for village customary land by the indigenous people of Bali is built by compliance and legal awareness that is inherent and built by a positive and strong legal culture. Although the implementation of the contents of the agreement was made verbally in the form of an agreement through a paruman/meeting with the approval of the chief Bendesa of the Pakraman village and the local villagers; this shows that the legal culture of indigenous peoples prioritizes the values of togetherness and respects the agreement agreed beforehand.

\section{Acknowledgement}

On this occasion, we would like to thank:

1. Rector of Udayana University;

2. Dean of the Faculty of Law, Udayana University;

3. Chairman of the Udayana University Research and Community Service Institute;

4. Chairman and colleagues at the Department of Law and the Community of the Faculty of Law, Udayana University;

Colleagues of lecturers, especially the research team who cannot be mentioned one by one who both directly and indirectly provide material and immaterial support so that the publication output in this series of research activities can be completed.

\section{References}

Books :

Muhammad, Bushar. (1988). Pokok-Pokok Hukum Adat (Principles of Customary Law). Jakarta: Fouth Edition. PT. Pradnya Paramita.

Riswandi, Budi Agus and Syamsudin, M. (2005). Hak Kekayaan Intelektual dan Budaya Hukum (Intellectual Property Rights and Legal Culture). Jakarta: Rajawali Press.

Saragih, Djaren. (1984). Pengantar Hukum Adat Indonesia (Introduction to Indonesian Customary Law). Bandung: 
Second Edition. Tarsito.

Wulandari, C., Dewi. (2010). Hukum Adat Indonesia Suatu Pengantar (Indonesian Customary Law). Bandung: First Edition. PT. Refika Aditama.

Rahayu, Derita Prapti. (2014). Budaya Hukum Pancasila (Pancasila Legal Culture). Yogyakarta: Thafa Media.

Soemadiningrat, Ojte Saman. (2011). Rekonseptualisasi Hukum Adat Kontemporer (Reconceptualization of Contemporary Customary Law). Bandung: Alumni.

Salim. HS., H. And Nurbani, Erlies Septiana. (2011). Penerapan Teori Hukum pada Penelitian Tesis dan Disertasi (Application of Legal Theory in Thesis and Dissertation Research). Jakarta: Raja Grafindo Persada.

Suryabrata, Sumandi. (1992). Metodologi Penelitian (Research Methodology). Jakarta: CV. Rajawali.

\section{Legislations}

Law No. 5 of 1960 on the Basic Agrarian Policy Regulation.

Law No. 2 of 1960 on Share Farming Agreements.

Regulation of the Minister of Agrarian No. 4 of 1964 concerning the Guidelines for Implementation of Share Farming Agreement as amended by Presidential Instruction No.13 of 1980 on the Implementation of Law No. 2 of 2005 on Share Farming Agreement. 